\title{
Characterization of the interactions between chitosan/whey protein at different conditions
}

\author{
Lizhu YE ${ }^{1}$, Huibin $\mathrm{CHEN}^{1,2 *}$
}

\begin{abstract}
This research investigated the interaction between chitosan and whey protein molecules in terms of $\mathrm{pH}$ and heating. The FTIR, rheological analysis, turbidity, and zeta potential measurements were used to assess this interaction. At $\mathrm{pH} 4.0$, addition of low amount chitosan with chitosan/whey protein isolate (C/WPI) ratio of 1:5 effectively prevented the denaturation of whey proteins after heating, whereas high amount of chitosan (C/WPI,1:2) led to depletion flocculation. The combination of chitosan and whey proteins was electrostatic attracting at $\mathrm{pH} 5.5$ and 6.0. At low chitosan addition, the complexes formed at $\mathrm{pH} 5.5$ showed higher viscosity and the complexes formed at $\mathrm{pH} 6.0$ showed a shear-thinning behaviour. At high chitosan addition, the complexes showed high viscosity at $\mathrm{pH}$ 6.0. Heating led to the decrease of viscosity and increase of turbidity. The results manifested that chitosan and whey protein formed different complexes at $\mathrm{pH} 5.5$ and 6.0, and the complexation of C/WPI was influenced by heating and ratio of chitosan and whey proteins.
\end{abstract}

Keywords: chitosan; whey protein; molecule; interaction; $\mathrm{pH}$.

Practical Application: The interaction of C/WPI can be applied to improve the mechanical properties of chitosan-based films and the quality of whey protein gel.

\section{Introduction}

The interactions between polysaccharides and proteins play important roles in the macroscopic properties of food products. In recent years, food scientists have modified the interaction behaviour between proteins and polysaccharides by changing the environmental conditions, such as $\mathrm{pH}$, heating and homogenization, to produce products with desired texture and physicochemical properties (Abhyankar et al., 2011; Prateepchanachai et al., 2017). when a protein solution is mixed with a polysaccharide solution, the interaction between the two polymers could be segregative, co-soluble or associative (Duran et al., 2016). These interactions can be adopted to obtain different functionalities. For instance, Co-soluble polysaccharides can be used to improve heat stability of protein-enriched beverage (Gentès et al., 2010), protein/polysaccharide nanoparticles formed based on associative interaction can be used as carrier of bioactive compounds with improved bio-availability (Lee et al., 2012).

Chitosan was reported with antimicrobial properties against fungi and bacteria, and has been successfully designed to prolong the shelf life of a variety of food products (Di Pierro et al., 2011; Duran et al., 2016). Whey proteins are milk proteins with globular structures and an isoelectric point of 4.7-5.3, and are very sensitive to temperature (Shimada \& Cheftel, 1989). Whey proteins are widely used in food industry owing to their nutritional, gel forming, and emulsifying properties (Brumini et al., 2016; Soukoulis et al., 2017). Recently, the formation of chitosan and whey protein film was studied and addressed as new materials with desired properties (Kurek et al., 2014). The binding between chitosan and model protein were impacted by different molecular weight of chitosan (Brumini et al., 2016). Chitosan can interact with whey protein at low $\mathrm{pH}(<4.5)$, which was reported that slight attraction exists between whey protein and chitosan molecules, and this process is endothermic (Casal et al., 2006; Yang et al., 2015). While chitosan and whey protein have opposite charges at $\mathrm{pH}>5.3$, electrostatic attraction plays a dominant role, leading to the formation of C/WPI complexes.

The mechanisms of the interaction between whey protein and chitosan remain unclear. This study aimed to systemically demonstrate the interaction between chitosan (low molecular weight (MW) of $9.35 \mathrm{kDa}$ ) and whey proteins before and after heating under different $\mathrm{pH}$ and chitosan concentrations. The interaction of chitosan with whey proteins was characterized by Fourier transform infrared spectroscopy (FTIR), rheological analysis, and turbidity and zeta potential measurements.

\section{Materials and methods}

\subsection{Materials}

Chitosan (Sigma-Aldrich, St. Louis, MO, USA) with molecular weight of approximately $9.35 \mathrm{kDa}$, viscosity (1\% in $1 \%$ acetic acid at $25^{\circ} \mathrm{C}$ ) of $20 \mathrm{mPa} \cdot \mathrm{s}$, and $85 \%$ degree of deacetylation was used. Whey protein isolate (WPI) contained $93.7 \%$ protein and 
was provided by New Zealand Dairy Products (Alacen 895, Mississagua, ON). All solutions were prepared using analytical grade chemicals and distilled water.

\subsection{Preparation of C/WPI dispersions}

WPI solution with a concentration of $5 \%(\mathrm{w} / \mathrm{w})$ was prepared in distilled water at room temperature $\left(22^{\circ} \mathrm{C}\right)$ under stirring. The addition of sodium azide $(0.01 \%)$ was aimed to prevent bacterial growth. The WPI solution was filtered using a $0.45 \mu \mathrm{m}$ filter (Millipore, Fisher Science, ON) to remove any large particles, and then stored in a refrigerator $\left(4^{\circ} \mathrm{C}\right)$ overnight to achieve complete hydration. Chitosan solutions (1\% and $2.5 \%, \mathrm{w} / \mathrm{w}$ ) were prepared by dissolving in $100 \mathrm{mmol} \mathrm{L}^{-1}$ acetic acid solution with stirring at $22^{\circ} \mathrm{C}$. C/WPI dispersions were prepared by mixing chitosan solutions with WPI solution at a ratio of $1: 1$, and the WPI concentration was $2.5 \%(\mathrm{w} / \mathrm{w})$ in the final mixing dispersion. In the final dispersions, C/WPI ratios were varied at 1:5 (low) and 1:2 (high). Solutions $\mathrm{pH}$ of 4.0, 5.5 and 6.0 was adjusted using $2 \mathrm{~mol} \mathrm{~L}^{-1} \mathrm{HCl}$ or $\mathrm{NaOH}$, and kept at room temperature for $2 \mathrm{~h}$ to achieve equilibrium. All the $\mathrm{C} / \mathrm{WPI}$ dispersions were incubated in a water bath at $90^{\circ} \mathrm{C}$ for $10 \mathrm{~min}$ using $15 \mathrm{ml}$ glass tubes, with an additional $2 \mathrm{~min}$ for the samples to reach the final temperature. And ice water was used to cool down the tubes instantly.

\subsection{Turbidity measurements}

For turbidity determination, all the dispersions were diluted 10 times using corresponding $\mathrm{pH}$-adjusted ( $\mathrm{pH} 4.0,5.5$ and 6.0) water and mixed well. After that, the diluted dispersions absorption was measured at $600 \mathrm{~nm}$ under a spectrophotometer (Hitachi UV-1100).

\subsection{Particle size and zeta potential measurements}

To reduce the viscosity of the dispersions, 10 times dilution was used for all the samples. The hydrodynamic radius and zeta potential of different dispersions were analysed through dynamic light scattering (Zetasizer Nano, Worcestershire, UK). All determinations were carried out at $25^{\circ} \mathrm{C}$. The average size based on intensity was reported for radius values using cumulant analysis, and the zeta potential results were represented by absolute values $(\mathrm{mV})$.

\subsection{Rheological measurements}

The rheological properties of C/WPI dispersions were characterized by a steady flow test. The dispersions were subjected to shear rate ramp range from 10 to $300 \mathrm{~s}^{-1}$ ). All the measurements were performed using a controlled stress rheometer AR 1000 (TA Instruments Ltd., DE, USA) with temperature control. A cone and plate geometry with an angle $2.09^{\circ}$ was used and measurement gap of $0.51 \mu \mathrm{m}$ was set. The rheological measurements were carried out at $25^{\circ} \mathrm{C}$.

\subsection{Attenuated total reflection (ATR)-FTIR Analysis}

To enhance the detection signals, the C/WPI dispersions $(15 \mathrm{~mL})$ were transferred to Petri dishes with a diameter of $8 \mathrm{~cm}$ and dried at $35^{\circ} \mathrm{C}$ for $24 \mathrm{~h}$. The formed films were analysed by
Fourier transform infrared spectroscopy (FTIR) (IR Prestige-21 FTIR spectrometer, Shimadzu Corp., Tokyo, Japan), which is fixed with an Attenuated total reflection (ATR) accessory (Pike Technologies, Madison, WI, USA). The films were placed on the ATR crystal with a press and analyzed from 600 to $4000 \mathrm{~cm}^{-1}$ at $4 \mathrm{~cm}^{-1}$ resolution. Air was used as background and 40 scans were averaged to give the final spectrum at room temperature $\left(22^{\circ} \mathrm{C}\right)$.

\subsection{Statistical analysis}

Each test was conducted with three or four replicates. ANOVA and Tukey's HSD (Minitab Inc., State College, PA, USA) were applied to analyse the experimental data with $95 \%$ confidence level.

\section{Results and discussion}

\subsection{Changes in turbidity}

As shown in Figure 1, all the dispersions had very low turbidity before heat treatment at low concentration of chitosan (C/WPI ratio of 1:5). The lowest turbidity was observed at $\mathrm{pH}$ 4.0. After heat treatment, no change in the turbidity was detected for the dispersion at $\mathrm{pH}$ 4.0. By contrast, at relatively high $\mathrm{pH}$ ( $\mathrm{pH} 5.5$ and 6.0), the turbidity increased rapidly after heating.

The addition of high amount of chitosan (C/WPI ratio 1:2) increased the turbidity significantly $(\mathrm{p}<0.05)$ at $\mathrm{pH} 5.5$ and 6.0 , whereas no significant change of the turbidity was detected at $\mathrm{pH} 4.0$ (Figure 1). After heating, the turbidity increased significantly with the appearance of some visible flocculence at $\mathrm{pH}$ 4.0. Similarly, the turbidity for dispersions with $\mathrm{pH} 5.5$ and 6.0 increased significantly after heat treatment. At $\mathrm{pH} 6.0$, the turbidity of the dispersion with C/WPI ratio of 1:2 was lower than that of the dispersion with C/WPI ratio of 1:5.

Turbidity is a concisely and widely used parameter to observe the behaviour changes of proteins and polysaccharides (Kurukji et al., 2016). In the present study, at $\mathrm{pH} 4.0$, heat treatment did not affect the turbidity when the concentration of chitosan was low (C/WPI ration 1:5), which is in agreement with previous research (Lee \& Hong 2009). By contrast, relatively high $\mathrm{pH}$ values ( $\mathrm{pH} 5.5$ and 6.0) increased the turbidity rapidly after heating. Meanwhile, C/WPI at a ratio of 1:2 did not change the turbidity at $\mathrm{pH} 4.0$, whereas turbidity changed significantly

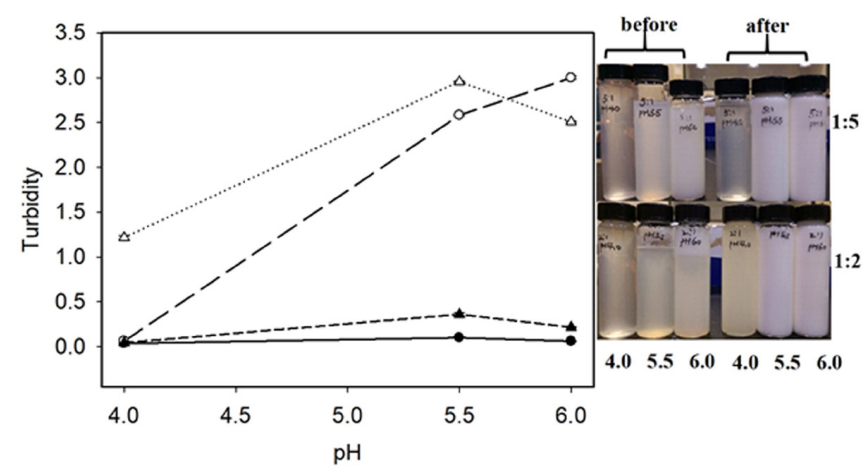

Figure 1. Turbidity of C/WPI dispersions with low $(\bullet, 0)$ and high $(\Delta, \mathbf{\Delta})$ chitosan levels before $(\boldsymbol{\Lambda}, \bullet)$ and after $(0, \Delta)$ heating. 
at pH 5.5 and 6.0. Different results were observed for the bovine serum albumin-chitosan and sodium caseinate-chitosan systems, where the turbidity decreased with increasing chitosan concentration at pH 5.0-6.0 (Kurukji et al., 2016). The highest turbidity was observed at $\mathrm{pH} 5.5$.

\subsection{Zeta potential}

For the whey proteins, the measured zeta potential values were $12 \pm 0.3,-16 \pm 0.3$ and $-19 \pm 0.6$ at $\mathrm{pH} 4.0,5.5$ and 6.0, respectively (Figure 2). The zeta potential decreased with the increase of $\mathrm{pH}$ was observed in our experiment, in agreement with previous report that the zeta potential of pure chitosan decreased significantly when $\mathrm{pH}$ increased for all cases (Mounsey et al., 2008). After addition of chitosan, the zeta potential for all dispersions was positive with considerably higher values. At $\mathrm{pH}$ 4.0, the C/WPI dispersions had a zeta potential of around $50 \mathrm{mV}$, which was independent of the chitosan concentration and the heat treatment. At pH 5.5 and 6.0, at which the chitosan and WPI were oppositely charged, the zeta potential changed from negative to positive. Similar to the previous study, when mixed chitosan and protein the $\mathrm{pH}$ of the mixture of can change to 5-5.5 and both of them are positively charged (Kurek et al., 2014). After heat treatment, the zeta potential at both low (1:5) and high (1:2) chitosan addition increased significantly.

The zeta potential values of the whey proteins were positive with much higher values after adding chitosan. Meanwhile, the zeta potential for C/WPI dispersions was independent of chitosan concentration and heat treatment at $\mathrm{pH}$ 4.0. The increase of the zeta potential indicated that the existence of a combination behaviour between whey proteins and chitosan, even though both of them are positively charged at low $\mathrm{pH}$. The combination of these two molecules was due to the interaction between negatively charged groups on the protein surface and the positively charged groups on the chitosan (Guzey \& Mcclements 2006).

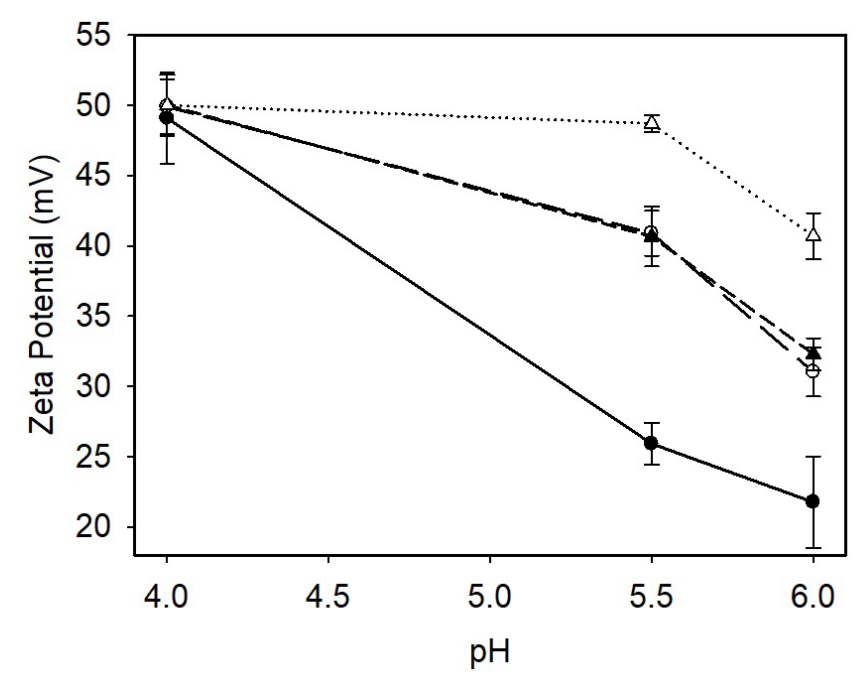

Figure 2. Zeta potential of C/WPI dispersions with low $(\bullet, 0)$ or high $(\Delta, \mathbf{\Lambda})$ chitosan levels before $(\boldsymbol{\Delta}, \bullet)$ and after $(\Delta, 0)$ heating.

\subsection{Rheological properties}

To further understand the interaction between chitosan and whey proteins at different $\mathrm{pH}$, a steady flow test $\left(10-300 \mathrm{~s}^{-1}\right)$ was used to investigate the rheological properties of C/WPI dispersions (Figure 3). Figure 3A showed the flow behaviours of dispersions with low chitosan concentration (C/WPI 1:5) at different $\mathrm{pH}$. Previous studies demonstrated that a $0.5 \%$ chitosan solution behaves as a Newtonian fluid (Hwang \& Shin, 2000; El-Hefian \& Yahaya, 2010). In present work, the dispersions at $\mathrm{pH} 4.0$ and 5.5 behaved as Newtonian fluids, but the dispersion at $\mathrm{pH} 5.5 \mathrm{had}$ a considerably high apparent viscosity. After heating, the dispersions still showed remarkable Newtonian fluid behaviour. No change in viscosity was detected at $\mathrm{pH}$ 4.0. By contrast, the viscosity for dispersion significantly decreased at $\mathrm{pH} 5.5$ after heat treatment. With further increase in $\mathrm{pH}$ to 6.0 , the apparent viscosity decreased with increasing shear rate, which indicated a good shear thinning behaviour. The radii at pH 5.5 and 6.0 were $190 \pm 1 \mathrm{~nm}$ and $283 \pm 8 \mathrm{~nm}$, respectively. Therefore, the appearance of shear-thinning behaviour was a result of the formation of C/WPI complexes. The different flow behaviours at $\mathrm{pH} 5.5$ and $\mathrm{pH} 6.0$ indicated that C/WPI complexes were formed, although their attractions were both dominated by electrostatic attractions. The average radius of the dispersions was lower at $\mathrm{pH} 5.5$ than at $\mathrm{pH} 6.0$, which indicated that more compact and homogeneous particles were formed at $\mathrm{pH} 5.5$.

The dispersions of C/WPI (1:2) at different $\mathrm{pH}$ all showed shearthinning behaviour, as shown in Figure 3B-3D. The dispersions at pH 5.5 and 6.0 showed lower apparent viscosity after heat treatments. By contrast, the dispersion of C/WPI at $\mathrm{pH} 4.0$ showed a much higher viscosity after heating. For a better comparison of the formation of different complexes on the rheological properties of C/WPI dispersions, the values of apparent viscosity at $300 \mathrm{~s}^{-1}$ are shown in Figure 4 . The highest viscosity was observed at $\mathrm{pH}$ 5.5 for low chitosan concentration (Figure 4A). The viscosity for dispersions at $\mathrm{pH} 5.5$ and 6.0 remarkably decreased after heating, whereas no change was detected at $\mathrm{pH}$ 4.0. At high chitosan concentration (Figure 4B), the viscosity increased with increase of $\mathrm{pH}$ and the highest viscosity was observed at $\mathrm{pH}$ 6.0. Similar trends were found after heat treatment.

The C/WPI (1:2) dispersion with high chitosan content showed shear-thinning behaviour at different $\mathrm{pH}$. In this case, attributing this phenomenon to the formation of C/WPI complexes is difficult because pure chitosan solution behaves as non-Newtonian fluid at concentration higher than $1 \%$ (Hwang \& Shin, 2000). The dispersion at $\mathrm{pH} 4.0$ before heating had higher viscosity than after heating, whereas the lower apparent viscosity was observed in the dispersions at pH 5.5 and 6.0 after heating. Two possible reasons could lead to the increase in viscosity: the occurrence of flocculent and the increase in segregative interaction after heat treatment (De Kruif \& Tuinier, 2001).

\subsection{FTIR analysis}

Three regions in the FTIR spectra were investigated, i.e., the amide I (1600-1690 $\left.\mathrm{cm}^{-1}\right)$ and amide II (1480-1575 $\left.\mathrm{cm}^{-1}\right)$ (Figure 5), as well as the bands in the $1280-1350 \mathrm{~cm}^{-1}$ region (Figure 6), which has been used as an indicator of protein $\alpha$-helix 


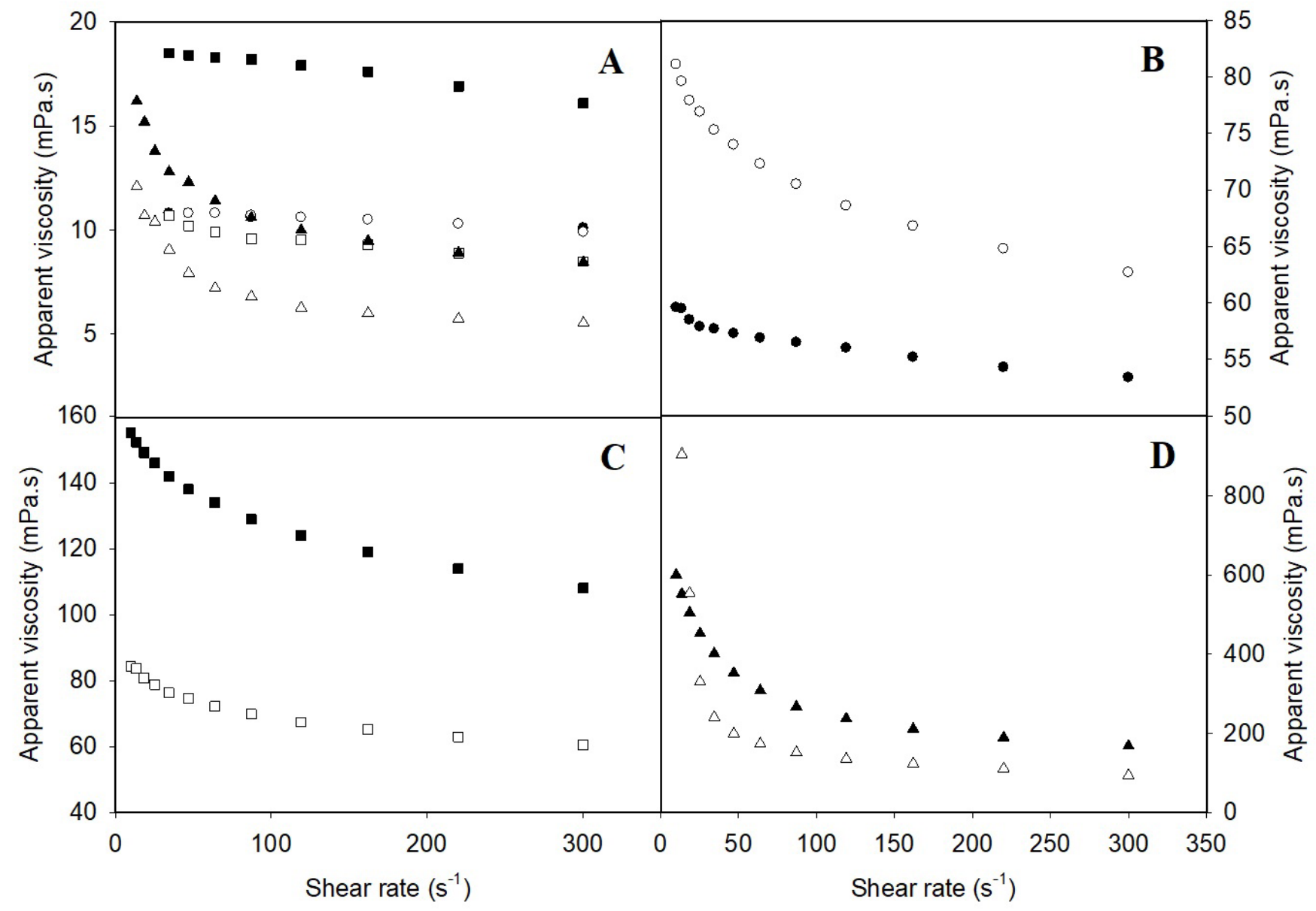

Figure 3. Rheological properties of C/WPI dispersions with low (A) or high (B-D) chitosan levels before $(\bullet, \bullet, \mathbf{\Delta})$ and after $(\circ, \square, \Delta)$ heating. pH $4.0(\bullet, 0)$, pH $5.5(\bullet, \square)$ and $\mathrm{pH} 6.0(\Delta, \mathbf{\Delta})$.

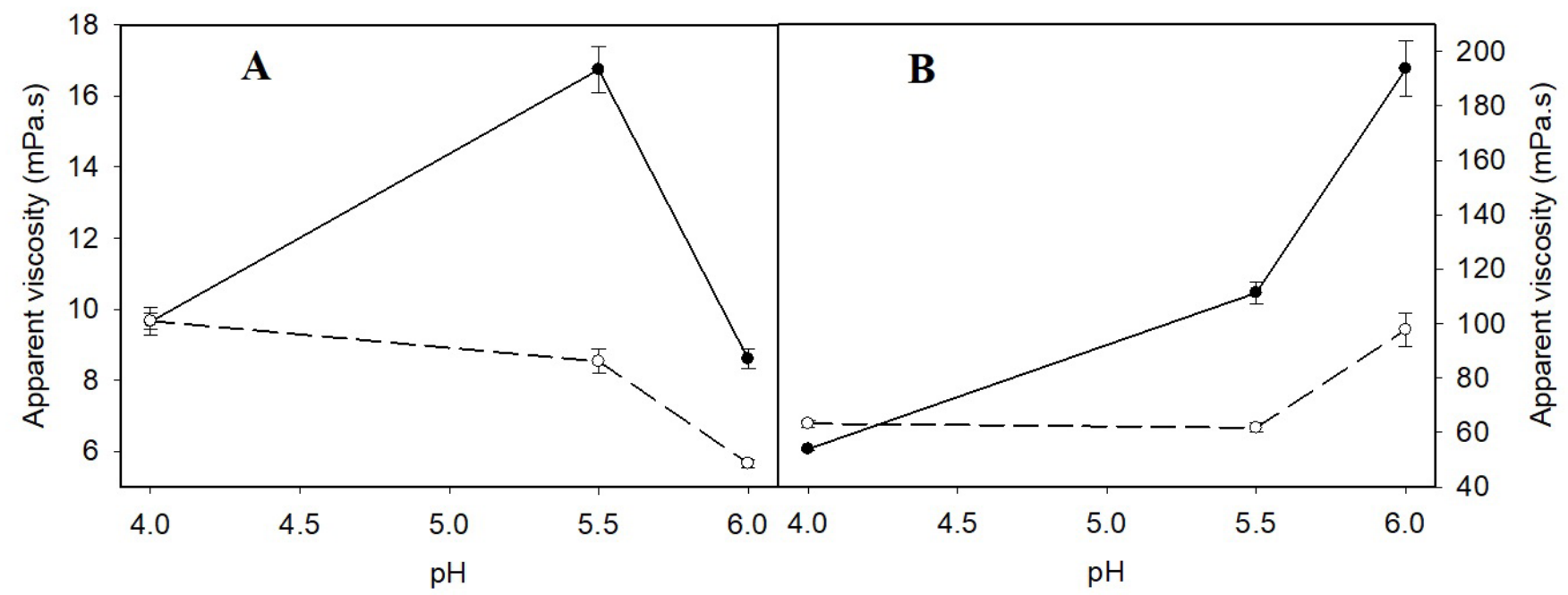

Figure 4. Apparent viscosity measured at $300 \mathrm{~s}^{-1}$ for C/WPI dispersions with low (A) or high (B) chitosan levels before (•) and after (०) heating.

orientation (Tsuboi et al., 2000). As shown in Figure 5, two bands (1516 and $1533 \mathrm{~cm}^{-1}$ ) could be detected in the amide II region, which were reported to be from the $\mathrm{N}-\mathrm{H}$ in-plane bending and C-N stretching mode (Bandekar \& Krimm, 1979; Kong \& Yu,
2007). The band in $1516 \mathrm{~cm}^{-1}$ is the $\mathrm{N}-\mathrm{H}$ in-plane bending from the specific group $\mathrm{NH}_{3}{ }^{+}$(Olsztyńska-Janus et al., 2010). At pH 4.0 (Figure $5 \mathrm{~B}$ ), both the bands absorbed at 1516 and $1533 \mathrm{~cm}^{-1}$ were seen, and no changes presented before or after heat 


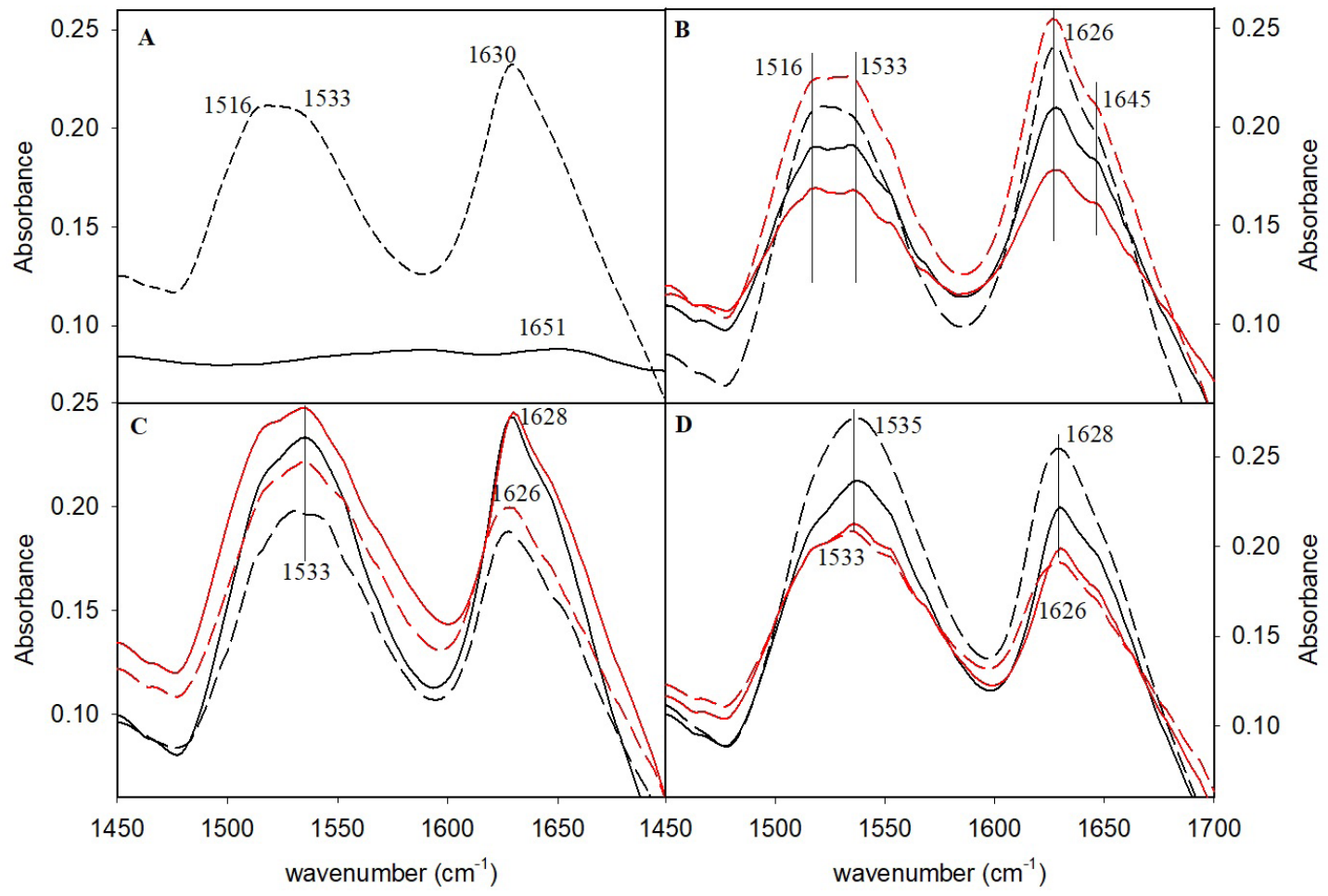

Figure 5. FTIR spectra (1450-1700 $\left.\mathrm{cm}^{-1}\right)$ of C/WPI dispersions at pH 4.0 (B), pH 5.5 (C), and pH 6.0 (D). Dispersions with different chitosan levels measured before and after heating: C/WPI 1:5 before heating (red solid line), C/WPI 1:5 after heating (red dashed line), C/WPI 1:2 before heating (black solid line) and C/WPI 1:2 after heating (black dashed line). The spectra for chitosan (solid line) and whey protein (dashed line) are shown as Figure 5A for comparison.

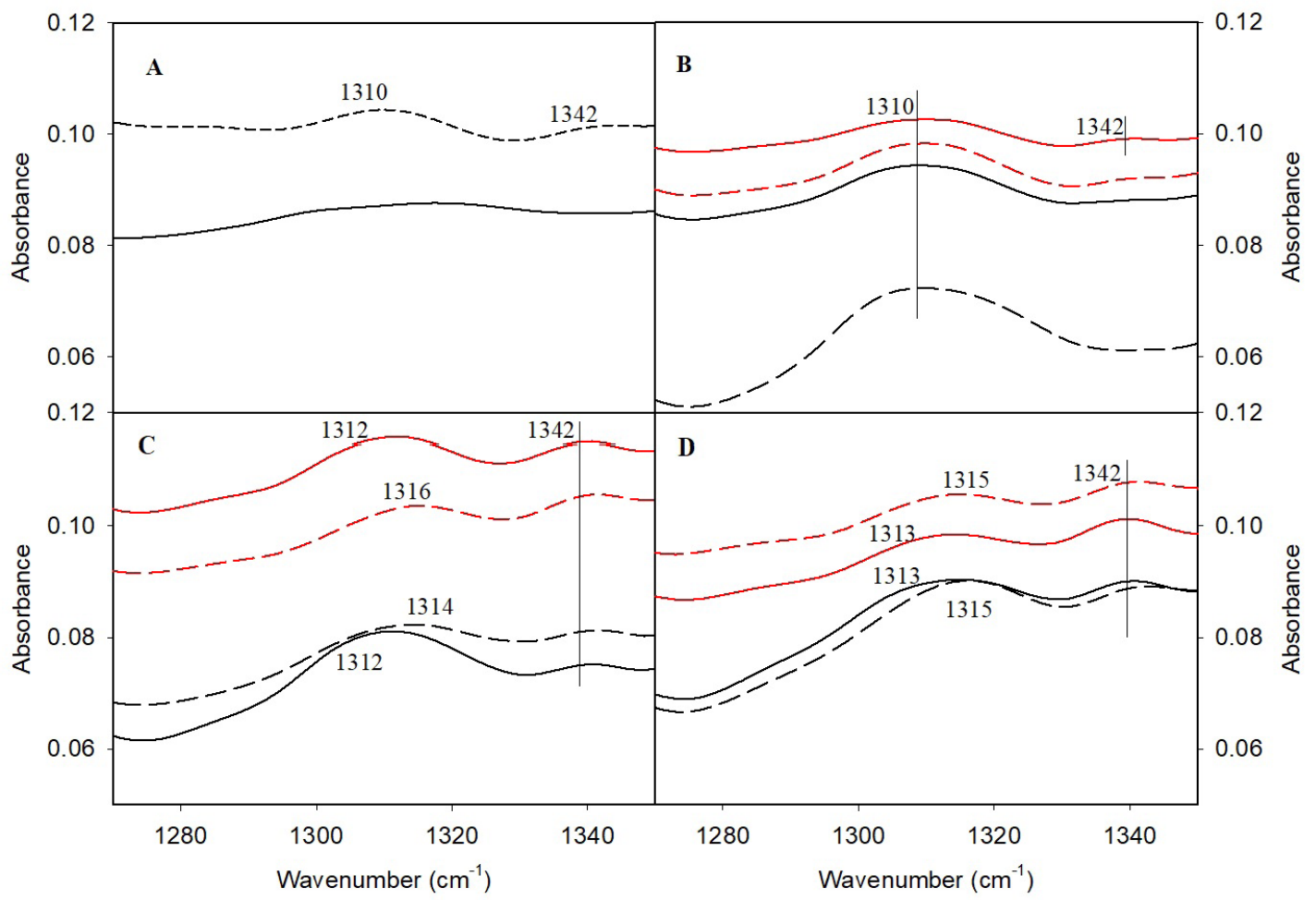

Figure 6. FTIR spectra (1250-1350 $\left.\mathrm{cm}^{-1}\right)$ of C/WPI dispersions at pH 4.0 (B), pH 5.5 (C), and pH 6.0 (D). Dispersions with different C/WPI ratio before and after heating: C/WPI 1:5 before heating (red solid line), C/WPI 1:5 after heating (red dashed line), C/WPI 1:2 before heating (black solid line) and C/WPI 1:2 after heating (black dashed line). The spectra for chitosan (solid line) and whey protein (dashed line) are shown as Figure 6A for comparison. 
treatment. By contrast, the addition of chitosan at $\mathrm{pH}$ (5.5 and 6.0) decreased the intensity of the band at $1516 \mathrm{~cm}^{-1}$, which was further influenced by heat treatment (Figure 5C and 5D). This phenomenon was due to the combination of chitosan with protein molecules, which restricted the bending motion of $\mathrm{NH}_{3}^{+}$groups. This band disappeared at high chitosan addition (C/WPI of 1:2) after heating (Figure 5D), thus indicating that heating promoted the complexation behaviour of whey protein and chitosan.

Compared to amide II, amide I (1600-1690 $\left.\mathrm{cm}^{-1}\right)$ was more susceptible to the protein secondary structure and predominately related to the $\mathrm{C}=\mathrm{O}$ stretching vibration of the amide group (Jiang et al., 2010). The main band detected at $1630 \mathrm{~cm}^{-1}$ in the current research arises from the $\beta$-sheet structures (Fang \& Dalgleish, 1997). The peak at $1650 \mathrm{~cm}^{-1}$ in the chitosan spectrum (Figure 5A) was attributed to acetylated amino group (Maachou et al., 2008; Yang et al., 2015). The mixture of chitosan and whey proteins showed a shift in the peak at $1630 \mathrm{~cm}^{-1}$ to a lower wavenumber at all $\mathrm{pH}$ values (Figure 5B-5D), which is consistent with previous research (Bourbon et al., 2011). In addition, the peak at $1650 \mathrm{~cm}^{-1}$ in the chitosan spectrum is shown in Figure 5A. The mixture of chitosan and whey proteins showed a shift of the peak at $1630 \mathrm{~cm}^{-1}$ to a lower wavenumber at all $\mathrm{pH}$ values (Figure 5B-5D). Furthermore, this peak shifted further after heating at $\mathrm{pH} 5.5$ and 6.0. By contrast, the peak didn't shift after heating at $\mathrm{pH} 4.0$. Figure 6 shows the changes of peaks in the wavenumber range of $1280-1350 \mathrm{~cm}^{-1}$, and two significant peaks were detected in this range, namely, 1310 and $1342 \mathrm{~cm}^{-1}$ (Figure 6A). The interaction of chitosan and whey protein at high $\mathrm{pH}$ (5.5 and 6.0) shifted the peak from $1310 \mathrm{~cm}^{-1}$ to a longer wavenumber (Figure 6C and 6D). At pH 4.0, no shift of the peak could be detected (Figure 6D).

At pH 5.5 and 6.0, this peak was further shifted after heating, and this was due to the heat-induced unfolding or denaturation of whey protein molecules (Geara, 1999). At $\mathrm{pH}$ 4.0, no shift of the peak could be detected after heating, which further confirmed that the chitosan prevented the heating denaturation of whey protein at $\mathrm{pH} 4.0$. Moreover, the peak at $1650 \mathrm{~cm}^{-1}$, from the acetylated amino group of chitosan, was prominent and no shift was detected after heat treatment (Figure 5B). In present study, the complexation of C/WPI may restrain the $\mathrm{C}=\mathrm{O}$ stretching vibration of the acetylated amino group in chitosan at $\mathrm{pH}$ higher than 5.5 because the peak was less prominent and completely disappeared after heating at $\mathrm{pH}$ 6.0 (Figure 5D.). The peak at $1342 \mathrm{~cm}^{-1}$ was attributed to $\mathrm{C}^{\alpha}-\mathrm{H}$ bending and $\mathrm{C}-\mathrm{C}^{\alpha}$ stretching of internal coordinates of the main chain $(\mathrm{O}=\mathrm{C})-\mathrm{C}^{\alpha}-\mathrm{H}$ moiety (Tsuboi et al., 2000). At pH 4.0, the intensity of this peak decreased after the addition of chitosan and disappeared at higher chitosan concentration (Figure 6A). Thus, the electrostatic repulsion between two molecules may inhibit the mobility of the protein molecules.

\section{Conclusion}

The interactions of C/WPI are influenced by $\mathrm{pH}$, heating and ratio. The low amount of chitosan inhibited the heat-induced changes of the protein structures at $\mathrm{pH} 4.0$ and no changes of the peaks in the amide I and amide II regions were detected.
The chitosan and whey protein with opposite charges at pH 5.5 and 6.0 could combine with each other through electrostatic attraction. In addition, different combinations were detected at these two $\mathrm{pH}$ values, which were further influenced by chitosan concentration. At low chitosan addition (1:5), a much higher apparent viscosity was found at $\mathrm{pH} 5.5$ compared to that at $\mathrm{pH}$ 6.0. By contrast, the apparent viscosity was higher at $\mathrm{pH} 6.0$ when high amount of chitosan was added. Moreover, heating facilitated the combination of chitosan and whey proteins. The differences in the combination mechanism at the two $\mathrm{pH}$ values need further investigation. Chitosan is widely used to prepare hydrogels, films and fibers. This research showed that packaging materials with improved barrier and mechanical properties can be fabricated by modifying the interaction between chitosan and proteins.

\section{Acknowledgements}

This work was jointly supported by National Natural Science Foundation of China (NO: 31401564), China Postdoctoral Science Foundation (NO: 2015M582030), Special Project for Marine High-technology Industry Development of Fujian Province (NO: [2014] 23), and Key Project of Xiamen Science and Technology Department (NO: 3502Z20163023). We also thank for Fund for Distinguished Young Scholars Development Program of Fujian's Universities and Colleges [2015].

\section{References}

Abhyankar, A. R., Mulvihill, D. M., Chaurin, V., \& Auty, M. A. E. (2011). Techniques for localisation of konjac glucomannan in model milk protein-polysaccharide mixed systems: Physicochemical and microscopic investigations. Food Chemistry, 129(4), 1362-1368. http://dx.doi.org/10.1016/j.foodchem.2011.05.052.

Bandekar, J., \& Krimm, S. (1979). Vibrational analysis of peptides, polypeptides, and proteins: characteristic amide bands of $\beta$-turns. Proceedings of the National Academy of Sciences of the United States of America, 76(2), 774-777. PMid:16592622.

Bourbon, A. I., Pinheiro, A. C., Cerqueira, M. A., Rocha, C. M. R., Avides, M. C., Quintas, M. A. C., \& Vicente, A. A. (2011). Physicochemical characterization of chitosan-based edible films incorporating bioactive compounds of different molecular weight. Journal of Food Engineering, 106(2), 111-118. http://dx.doi.org/10.1016/j. jfoodeng.2011.03.024.

Brumini, D., Criscione, A., Bordonaro, S., Vegarud, G. E., \& Marletta, D. (2016). Whey proteins and their antimicrobial properties in donkey milk: a brief review. Dairy Science \& Technology, 96(1), 1-14. http:// dx.doi.org/10.1007/s13594-015-0246-1.

Casal, E., Montilla, A., Moreno, F. J., Olano, A., \& Corzo, N. (2006). Use of chitosan for selective removal of $\beta$-lactoglobulin from whey. Journal of Dairy Science, 89(5), 1384-1389. http://dx.doi.org/10.3168/ jds.S0022-0302(06)72206-8. PMid:16606709.

De Kruif, C. G., \& Tuinier, R. (2001). Polysaccharide protein interactions. Food Hydrocolloids, 15(4-6), 555-563. http://dx.doi.org/10.1016/ S0268-005X(01)00076-5.

Di Pierro, P., Sorrentino, A., Mariniello, L., Giosafatto, C. V. L., \& Porta, R. (2011). Chitosan/whey protein film as active coating to extend Ricotta cheese shelf-life. Lebensmittel-Wissenschaft + Technologie, 44(10), 2324-2327. http://dx.doi.org/10.1016/j.lwt.2010.11.031. 
Duran, M., Aday, M. S., Zorba, N. N. D., Temizkan, R., Büyükcan, M. B., \& Caner, C. (2016). Potential of antimicrobial active packaging "containing natamycin, nisin, pomegranate and grape seed extract in chitosan coating" to extend shelf life of fresh strawberry. Food and Bioproducts Processing, 98, 354-363. http://dx.doi.org/10.1016/j. fbp.2016.01.007.

El-Hefian, E. A., \& Yahaya, A. H. (2010). Rheological study of chitosan and its blends: an overview. Maejo International Journal of Science and Technology, 4, 210-220.

Fang, Y., \& Dalgleish, D. G. (1997). Conformation of $\beta$-Lactoglobulin studied by FTIR: Effect of $\mathrm{pH}$, temperature, and adsorption to the oil-water interface. Journal of Colloid and Interface Science, 196(2), 292-298. http://dx.doi.org/10.1006/jcis.1997.5191. PMid:9792754.

Geara, C. (1999). Study of the gelation of whey protein isolate by FTIR spectroscopy and rheological measurements. Montreal: McGill University.

Gentès, M.-C., St-Gelais, D., \& Turgeon, S. L. (2010). Stabilization of whey protein isolate-pectin complexes by heat. Journal of Agricultural and Food Chemistry, 58(11), 7051-7058. http://dx.doi.org/10.1021/ jf100957b. PMid:20462219.

Guzey, D., \& Mcclements, D. J. (2006). Characterization of $\beta$-lactoglobulinchitosan interactions in aqueous solutions: A calorimetry, light scattering, electrophoretic mobility and solubility study. Food and Chemical Toxicology, 20, 124-131. http://dx.doi.org/10.1016/j. foodhyd.2005.03.009.

Hwang, J. K., \& Shin, H. H. (2000). Rheological properties of chitosan solutions. Korea-Australia Rheology Journal, 1244, 175.

Jiang, Y., Li, Y., Chai, Z., \& Leng, X. (2010). Study of the physical properties of whey protein isolate and gelatin composite films. Journal of Agricultural and Food Chemistry, 58(8), 5100-5108. http:// dx.doi.org/10.1021/jf9040904. PMid:20356044.

Kong, J., \& Yu, S. (2007). Fourier transform infrared spectroscopic analysis of protein secondary structures. Acta Biochimica et Biophysica Sinica, 39(8), 549-559. http://dx.doi.org/10.1111/j.1745-7270.2007.00320.x. PMid:17687489.

Kurek, M., Galus, S., \& Debeaufort, F. (2014). Surface, mechanical and barrier properties of bio-based composite films based on chitosan and whey protein. Food Packag ShelfLife, 1(1), 56-67. http://dx.doi. org/10.1016/j.fpsl.2014.01.001.

Kurukji, D., Norton, I., \& Spyropoulos, F. (2016). Fabrication of submicron protein-chitosan electrostatic complexes for encapsulation and $\mathrm{pH}$-Modulated delivery of model hydrophilic active compounds. Food Hydrocolloids, 53, 249-260. http://dx.doi.org/10.1016/j. foodhyd.2015.02.021.

Lee, A.-C., \& Hong, Y.-H. (2009). Coacervate formation of a-lactalbuminchitosan and $\beta$-lactoglobulin-chitosan complexes. Food Research
International, 42(5-6), 733-738. http://dx.doi.org/10.1016/j. foodres.2009.02.022.

Lee, P. S., Yim, S. G., Choi, Y., Van Anh Ha, T., \& Ko, S. (2012). Physiochemical properties and prolonged release behaviours of chitosan-denatured $\beta$-lactoglobulin microcapsules for potential food applications. Food Chemistry, 134(2), 992-998. http://dx.doi. org/10.1016/j.foodchem.2012.03.006. PMid:23107718.

Maachou, H., Bal, K. E., Bal, Y., Chagnes, A., Cote, G., \& Alliouchea, D. (2008). Characterization and in Vitro bioactivity of chitosan/ hydroxyapatite composite membrane prepared by freeze-gelation Method. Artif Organs Trends Biomater Artif Organs, 22(1), 16-27.

Mounsey, J. S., O’Kennedy, B. T., Fenelon, M. A., \& Brodkorb, A. (2008). The effect of heating on $\beta$-lactoglobulin-chitosan mixtures as influenced by $\mathrm{pH}$ and ionic strength. Food Hydrocolloids, 22(1), 65-73. http://dx.doi.org/10.1016/j.foodhyd.2007.04.006.

Olsztyńska-Janus, S., Gąsior-Głogowska, M., Szymborska-Małek, K., Czarnik-Matusewicz, B., \& Komorowska, M. (2010). Specific applications of vibrational spectroscopy in biomedical engineering. In M. A. Komorowska \& S. Olsztynska-Janus (Ed.), Biomedical Engineering, Trends, Research and Technologies (pp 91-121). Rijeka: InTech. http://dx.doi.org/10.5772/13121.

Prateepchanachai, S., Thakhiew, W., Devahastin, S., \& Soponronnarit, S. (2017). Mechanical properties improvement of chitosan films via the use of plasticizer, charge modifying agent and film solution homogenization. Carbohydrate Polymers, 174, 253-261. http://dx.doi. org/10.1016/j.carbpol.2017.06.069. PMid:28821066.

Shimada, K., \& Cheftel, J. C. (1989). Sulfhydryl group/disulfide bond interchange reactions during heat-induced gelation of whey protein isolate. Journal of Agricultural and Food Chemistry, 37(1), 161-168. http://dx.doi.org/10.1021/jf00085a038.

Soukoulis, C., Behboudi-Jobbehdar, S., Macnaughtan, W., Parmenter, C., \& Fisk, I. D. (2017). Stability of lactobacillus rhamnosus GG incorporated in edible films: impact of anionic biopolymers and whey protein concentrate. Food Hydrocolloids, 70, 345-355. http:// dx.doi.org/10.1016/j.foodhyd.2017.04.014. PMid:28867864.

Tsuboi, M., Suzuki, M., Overman, S. A., \& Thomas, G. J. Jr. (2000). Intensity of the polarized raman band at $1340-1345 \mathrm{~cm}$ as an indicator of protein $\alpha$-helix orientation: application to pf1 filamentous virus. Biochemistry, 39(10), 2677-2684. http://dx.doi.org/10.1021/ bi9918846. PMid:10704218.

Yang, N., Ashton, J., \& Kasapis, S. (2015). The influence of chitosan on the structural properties of whey protein and wheat starch composite systems. Food Chemistry, 179, 60-67. http://dx.doi.org/10.1016/j. foodchem.2015.01.121. PMid:25722139. 